\title{
PERLINDUNGAN DAN HAK PEKERJA PEREMPUAN DI BIDANG KETENAGAKERJAAN
}

\author{
Aulya Murfiatul Khoiriyah ${ }^{1}$
}

\begin{abstract}
Abstrak:
Tulisan ini bermaksud untuk mengetahui maraknya terjadi pelanggaran hak-hak normatif buruh perempuan, tingginya jumlah buruh perempuan di perusahaan-perusahaan tidak mengakibatkan peraturan di perusahaan menjadi sensitif gender, sering kali di dalam perusahaan terjadi penyimpangan yang menjadikan buruh perempuan diperlakukan semena-mena. Contoh, buruh perempuan yang sedang hamil dan tidak mendapatkan cuti. Perempuan mempunyai atas perlindungan yang khusus sesuai dengan fungsi reproduksinya sebagaimana diatur dalam pasal 11 ayat 1 CEDAW bahwa hak atas perlindungan kesehatan dan keselamatan kerja termasuk usaha perlindungan terhadap fungsi reproduksi. Para wanita boleh bekerja dalam berbagai bidang, didalam ataupun diluar rumahnya, baik secara mandiri maupun bersama orang lain. Karena setiap perempuan mempunyai hak asasi manusia yang diakui dan dilindungi oleh undang-undang. Jadi permasalahan di sini adalah, bagaimana kesetaraan gender terhadap hak pekerja perempuan di bidang ketenagakerjaan? dan bagaimana upaya agar wanita hamil dan menyusui mendapatkan perlindungan hukum dalam bidang ketenagakerjaan? Tulisan ini merupakan jenis penelitian kepustakaan (library researh) dengan menggunakan kajian pustaka yang mengambil sumber primer dan sekunder dari buku-buku, artikel. Dari tulisan dapat disimpulkan bahwa pada dasarnya hak-hak pekerja wanita sebagaimana tertera dalam Kovensi ILO terdiri dari kesetaraan upah, diskriminasi dalam pekerjaan dan jabatan, perlindungan kehamilan dan pekerja dengan tanggung jawab keluarga. Hak-hak tersebut telah diatur dalam hukum Indonesia yakni dalam UU no.13 tahun 2003 tentang ketenagakerjaan. Namun pada praktiknya masih banyak beberapa hak pekerja yang belum terpenuhi diberbagai perusahaan Indonesia. Mengenai ketenagakerjaan dalam pelaksanaannya diharuskan memenuhi hakhak dan perlindungan bagi tenaga kerja perempuan.
\end{abstract}

Kata kunci: kesetaraan gender, hak pekerja perempuan

\section{PENDAHULUAN}

Pembahasan tentang perempuan dengan menggunakan analisis gender sering mendapatkan perlawanan (resistance) baik dari kaum laki-laki maupun kaum perempuan, bahkan sering ditolak oleh mereka yang melakukan kritik terhadap sistem sosial dominan seperti kapitalis. Timbulnya perlawanan tersebut disebabkan pertama, mempertanyakan status perempuan pada dasarnya adalah mempersoalkan sistem dan struktur yang telah mapan, bahkan mempertanyakan posisi perempuan, yang dapat menggoncang struktur dan sistem status quo ketidakadilan dalam masyarakat. Kedua, banyak terjadi kesalahpahaman tentang mengapa masalah perempuan harus dipertanyakan. Kesulitan lain dalam mendiskusikan soal gender, pada dasarnya, berarti membahas hubungan kekuasaan yang sifatnya sangat pribadi, yakni menyangkut dan melibatkan masing-masing individu serta menggugat privelege yang kita miliki dan sedang kita nikmati selama ini.

\footnotetext{
1 Pascasarjana IAIN Ponorogo.
} 
Untuk mengenal lebih jauh perbedaan keduanya, perlu dipahami bahwa seks atau jenis kelamin merupakan pembagian manusia secara biologis yang melekat pada jenis kelamin tertentu, misalnya laki-laki memiliki penis, testis, jakala dan mereproduksi sperma. Sedangkan perempuan mempunyai vagina, rahim, indung, telur, payudara, dan air susu sehingga bisa haid, hamil dan menyusui, yang disebut dengan fungsi reproduksi. Alat-alat tersebut merupakan atribut yang melekat pada setiap manusia yang tidak dapat dipertukarkan. Itulah yang disebut dengan takdir. ${ }^{2}$ Tulisan ini menjelaskan bagaimana sebenarnya posisi, peran dan relasi gender, serta bagaimana membangun gender yang setara dan berkeadilan gender melalui peran dan kerja, baik dalam ranah publik, domestik maupun sosial.

\section{PEMBAHASAN}

\section{Konsep Gender dan Kesetaraan Gender}

Kata gender berasal dari bahasa Inggris, berarti jenis kelamin. Dalam webster's new world dictionary, gender diartikan sebagai perbedaan yang tampak antara laki-laki dan perempuan dilihat dari segi nilai dan tingkah laku. Dalam women's studies encyclopedia dijelaskan bahwa gender adalah suatu konsep kultural yang berupaya membuat perbedaan (distinction) dalam hal peran, perilaku, mentalitas, dan karakteristik emosional antara laki-laki dan perempuan yang berkembang masyarakat. Sedangkan Hilary M. Lips mengartikan gender sebagai harapanharapan budaya terhadap laki-laki dan perempuan (cultural expectations for women and men). Pendapat ini sejalan dengan pendapat kaum feminis, seperti Lindsey yang menganggap semua ketetapan masyarakat perihal penentuan seseorang sebagai laki-laki atau perempuan adalahtermasuk bidang kajian gender (what a given society defines as masculine or feminin is a component of gender). ${ }^{3}$

Gender sendiri sebenarnya memiliki definisi terminologis yang variatif, namun dmikian sesungguhnya ia saling melengkapi. Selain itu pembatasannya juga lebih banyak terkait dengan perbedaan antara laki-laki dan perempuan. Menurut Heyzer, gender adalah peranan laki-laki dan perempuan dalam suatu tingkah laku sosial yang terstruktur. Sedangkan Illich berpendapat gender dimaksudkan untuk membedakan antara laki-laki dan perempuan secara sosial, yang mengacu pada unsur emosional, kejiwaan, dan tingkah laku. Di sisi lain Letner mendefinisikan gender sebagai suatu tingkah laku yang sesuai dengan jenis kelamin pada suatu masyarakat yang dilaksanakan pada waktu tertentu. ${ }^{4}$

2 Mufidah,paradigma gender (Malang: bayumedia publishing, 2003), 2

${ }^{3}$ Sarifa Suhra, "kesetaraan gender dalam perspektif AL-Qur'an dan implikasinya terhadap hukum Islam", jurnal Al-Ulum, vol 13 no 2, desember 2013,hlm 376, dalam http:// www.journal.iaingorontalo.ac.id/index.php/au diakses pada 19 november 2019 pukul 12.00 WIB.

${ }^{4}$ Andik Wahyun Muqoyyidin, "wacana kesetaraan gender pemikiran Islam kontemporer tentang gerakan feminisme Islam", jurnal Al-Ulum, vol 13 no 2, desember 2013, hlm 495-496, dalam 
Pengertian lain tentang gender sebagaimana dirumuskan oleh Mansour Fakih, gender adalah suatu sifat yang melekat pada kaum laki-laki maupun perempuan yang dikonstruksi secara sosial dan cultural. Sifat gender yang melekat pada perempuan misalnya, perempuan itu dikenal lemah lembut, cantik, emosional, atau keibuan. Sementara laki-laki dianggap kuat, rasional, jantan, perkasa. Ciri dari sifatsifat tersebut merupakansifat yang dapat dipertukarkan antara kaum laki-laki dan perempuan. Artinya, ada laki-laki yang emosional, lemah lembut, keibuan, sementara juga ada perempuan yang kuat, rasional, perkasa. ${ }^{5}$

Beberapa definisi diatas, dapat disimpulkan bahwa gender suatu konsep yang digunakan untuk mengidentifikasi perbedaan laki-laki dan perempuan dilihat dari segi pengaruh sosial budaya. Gender merupakan perbedaan peran laki-laki dan perempuan yang di konstruksi (dibangun) oleh masyarakat atau kelompok masyarakat dengan latar belakang budaya dan struktur sosial yang berbeda-beda disetiap daerah, suku, negara, dan agama. Oleh karena itu, perbedaan peran, perilaku dan sifat laki-laki dan perempuan yang berlaku disuatu tempat/budaya belum tentu sama atau berlaku ditempat yang berbeda.

Diskriminasi terhadap perempuan yang terus terjadi di berbagai belahan dunia masih menunjukkan bahwa pemahaman serta usaha-usaha untuk mewujudkan kesetaraan gender masih banyak menemukan kendala. Masih kuatnya budaya patriarkhis masih memposisikan perempuan pada stereotype, peran dan posisi yang termarginalkan. Padahal relasi yang seimbang (kesetaraan gender) antara laki-laki dan perempuan dalam segala aspek kehidupan dapat mendorong percepatan proses pembangunan yang dilandasi nilai-nilai kemanusiaan yang tinggi tanpa adanya imperioritas satu jenis kelamin di satu sisi dan superioritas jenis kelamin di sisi lainnya.

Dengan demikian, suatu paradigma baru sangat diperlukan untuk memberikan kerangka dan menjelaskan hubungan (relasi) antara perempuan dan laki-laki di berbagai lapisan masyarakat, lembaga formal maupun lembaga informal, termasuk institusi keluarga. Strategi-strategi untuk perubahan diperlukan yaitu bagaimana melakukan perubahan hubungan (relasi) antara perempuan dan laki-laki yang responsif gender sehingga terwujud kesetaraan dan keadilan gender. ${ }^{6}$

http://www.journal.iaingorontalo.ac.id/index.php/au diakses pada 19 november 2019 pukul 12.00 WIB.

${ }^{5}$ Ridwan, kekerasan berbasis gender (Purwokerto: fajar pustaka, 2006), 16

${ }^{6}$ Anita Rahmawaty, "harmoni dalam keluarga perempuan karir: upaya mewujudkan kesetaraan dan keadilan gender dalam keluarga", jurnal palastren, vol 8 no 01 juni 2015, hlm 7-8, dalam https://www.ingentaconnect.com/content/doaj/19796056/2016/00000008/00000001/art00001/sup p-data;jsessionid=2wppn6nk82jsk.x-ic-live-01 diakses pada 20 november 2019 pukul 09.20 WIB. 


\section{Bentuk-bentuk Ketidakadilan Gender \\ Marginalisasi perempuan ${ }^{7}$}

Marginalisasi itu merupakan proses pemiskinan perempuan terutama pada masyarakat lapis bawah sangat memprihatinkan kesejahteraan keluarga mereka. Demikian pula, marginalisasi dalam lingkungan keluarga biasa terjadi ditengah masyarakat, misalnya anak laki-laki memperoleh fasilittas, kesempatan dan hak-hak yang lebih daripada anak perempuan. Budaya semacam ini selalu diperkuat oleh penafsiran agama, adat istiadat sehingga perempuan selalu menjadi korban ketidakadilan gender akibat marginalisasi perempuan tersebut.

a. Penempatan perempuan pada subordinasi

Sebuah pandangan yang tidak adil terh adap perempuan dengan anggapan dasar bahwa perempuan itu irasional, emosional, lemah dan lain-lainnya, menyebabkan penempatan perempuan dalam peran-peran yang dianggap kurang penting. Potensi perempuan sering di nilai tidak fair oleh sebagian besar masyarakat kita mengakibatkan sulitnya mereka menembus posisi-posisi strategis dalam komunitasnya, terutama yang berhubungan dengan peran pengambilan keputusan. Jika perempuan mampu meraih posisi tersebut, berarti ia telah berhasil dalam kompetisi yang sangat ketat dan perjuangan yang cukup panjang, tidak sebagaimana yang dilakukan oleh laki-laki. Agama sering juga dipakai sebagai pengukuh dari pandangan semacam itu sehingga perempuan selalu menjadi bagian dari laki-laki.

b. Stereotype perempuan

Stereotype adalah pelabelan terhadap kelompok, suku, bangsa tertentu yang selalu berkonotasi negatif sehingga sering merugikan dan timbul ketidakadilan. Pelabelan atau penandaan yang dikaitkan dengan perbedaan jenis kelamin tertentu (perempuan) akan menimbulkan kesan negatif yang merupakan keharusan disandang oleh perempuan. Stereotype itu merupakan salah satu bentuk ketidakadilan gender. Misalnya, suatu dugaan bahwa perempuan itu suka bersolek untuk menarik perhatian lawan jenis. Jika terjadi kasus perkosan, selalu disimpulkan bahwa kejadian tersebut berawal dari label perempuan, tanpa harus menganalisis sisi-sisi lain yang menjadi faktor penyebab terjadinya perkosaan itu. Karena itu, kasus perkosaan dipandang sebagai kesalahan perempuan, ia dianggap sebagai sumber fitnah terjadinya perkosaan itu. Karena itu, kasus perkosaan dipandang sebagai kesalahan perempuan, ia dianggap sebagai sumber fitnah terjadinya perkosaan, yang semua itu berangkat dari stereotype pada perempuan secara umum. Demikian pula, perempuan adalah jenis manusia yang lemah fisik maupun intelektualnya sehingga tidak layak untuk menjadi pemimpin, karena itu sarat dengan keterbatasan tidak sebagaimana laki-laki. Aktivitas laki-laki lebih

${ }^{7}$ Ibid, 26 
leluasa, bebas, lebih berkualitas, dan produktif. Keterpurukan itu semaki parah dengan mencari legitimasi agama yang disalahtafsirkan.

c. Kekerasan (violence) terhadap perempuan

Salah satu bentuk ketidakadilan gender adalah tindak kekerasan terhadap perempuan baik yang berbentuk kekerasan fisik maupun psikis. Kekerasan timbul akibat beberapa faktor di atas, termasuk anggapan bahwa laki-laki pemegang supremasi dan dominasi terhadap berbagai sektor kehidupan. Femomena itu oleh masyarakat dianggap sebagai sesuatu yang wajar jika perempuan menerima perlakuan tersebut. Kekerasan terhadap perempuan mempunyai beberapa tingkatan, yaitu pemerkosaan, pemukulan, penganiayaan dan pembunuhan, prostitusi sebagai bentuk eksploitasi perempuan, pornografi sebagai bentuk pelecehan, eksploitasi perempuan pada dunia kerja dan hiburan, pemaksaan strerilisasi dalam keluarga berencan, dan pelecehan seksual dengan sentuhan maupun ungkapan yang merendahkan martabat perempuan.

Seluruh tindakan tersebut dapat digolongkan pada pelanggaran hak asasi manusia yang semestinya dihormati oleh siapa pun tanpa memandang gendernya. Tindakan yang paling rendah dari tingkat kekerasan terhadap perempuan tersebut melahirkan berbagai ketidakharmonisan sosial yang menghambat perkembangan psikis perempuan. Selanjutnya akan memupuk subur infesrioritas perempuan dengan sekian banyak ketidakberdayaan.

d. Beban kerja yang tidak proporsional

Budaya patriarki beranggapan bahwa perempaun tidak punya hak untuk menjadi pemimpin rumah tangga. Sebaliknya, ia berhak untuk diatur, pekerjaan domestik yang dibebankan kepadanya menjadi identik dengan dirinya sehingga posisi perempuan sarat dengan pekerjaan yang beragam macamnya, dalam waktu yang tidak terbatas dan dengan beban yang cukup berat, misalnya: memasak, mencuci, seterika, menjaga kebersihan dan kerapian rumah, membimbing belajar anak-anak dan sebagainya. Pekerjaan domestik yang berat tersebut dilakukan bersam-sama dengan fungsi reproduksi, haid, hamil, melahirkan dan menyusui. Sementara laki-laki dengan peran publiknya menurut kebiasaan masyarakat (konstruk sosial), tidak bertanggung jawab terhadap beban kerja domestik, karena hanya layak dikerjakan oleh perempuan.

Bentuk-bentuk ketidakadilan gender melalui marginalisasi, penempatan perempuan pada subordinat, stereotype, tindak kekerasan, maupun beban kerja yang tidak proporsional dilakukan oleh laki-laki dalam segala komunitas yang ada. Hal itu dapat terjadi dalam lingkungan keluarga, ditempat-tempat kerja, ditempat-tempat umum, dan dapat pula dilakukan oleh siapa saja yang tidak peka pada persoalan gender dan kemanusiaan. Karena itu, wawasan 
tentang gender tidak ditentukan oleh status sosial, tingkat pendidikan maupun profesi seseorang, tetapi lebih dipengaruhi oleh wawasan tentang gender tersebut. Untuk mengikis konstruksi sosial budaya yang tidak berkeadilan gender, tentu saja kita harus memahami dulu konsep kesetaraan. Kesetaraan bukan dalam arti sama rata dan tidak ada perbedaan. Dalam konteks tersebut kesetaraan lebih tepat dimaknai dengan berkeadilan dan berkeseimbangan. ${ }^{8}$

\section{Hak Bagi Pekerja Perempuan}

Pertanyaan, apakah wanita yang sama seperti orang atau yang berbeda dari mereka telah bermain keluar dalam amerika sebagian besar melalui diskusi dan litigasi tentang kehamilan, khususnya cuti hamil ketentuan. Hanya beberapa negara di AS telah istimewa cuti hamil secara hukum. Ini telah menantang sebagai yang melanggar hukum federal dari american anti diskriminasi, atas dasar bahwa mereka memperlakukan wanita hamil lebih baik daripada tanpa hamil pekerja yang tidak dapat bekerja untuk alasan lain. Seperti tantangan yang telah didukung oleh "sama perawatan" atau "ketat pengobatan identik" feminis yang berpendapat bahwa "kehamilan dapat atau harus membayangkan sebagai salah satu pengalaman manusia yang banyak di contexts, yang paling terutama tempat kerja, menciptakan membutuhkan dan masalah yang mirip dengan orang-orang yang timbul dari disebabkan lain dari kehamilan, dan yang bisa ditangani cukup didasar yang sama seperti yang lain kondisi fisik karyawan. ${ }^{9}$

Pekerja wanita harus mendapatkan perlindungan khusus terkait dengan kodrat yang melekat pada dirinya yaitu ketika masa haid (datang bulan), kehamilan, melahirkan, dan menyusui anak. Hamil, melahirkan serta menyusui anak merupakan hak asasi manusia sebagaimana yang diatur dalam pasal 10 ayat $1 \mathrm{UU}$ Nomor 39 tahun 1999 tentang hak asasi manusia "setiap orang berhak membentuk suatu keluarga dan melanjutkan keturunan melalui perkawinan yang sah". Dengan didasarkan kepada pasal 10 ayat 1 UU nomor 39 tahun 1999 tentang hak asasi manusia, negara Indonesia telah menghormati dan melindungi pekerja wanita terkait dengan hak reproduktif. Sehingga terhadap hal tersebut, perusahaanperusahaan yang memperkerjakan pekerja harus memberikan perlindungan hukum terhadap pekerja wanita terkait hak reproduktif. Walaupun sudah diatur dalam beberapa instrumen hukum, namun masih banyak pelanggaran yang dilakukan perusahaan terhadap pekerja wanita. $^{10}$ Di Amerika seks diskriminasi telah diberlakukan undang-undang tersebut dapat dipahami, kehamilan diskriminasi

${ }^{8}$ Mufidah, paradigma gender (Malang: bayumedia publishing, 2003), 52-54

${ }^{9}$ Regina Grayer, the hidden gender of law (Australia: the federation press, 1990), 44

${ }^{10}$ Desia Rakhma Banjarani "pelaksanaan dan perlindungan akses hak pekerja wanita di Indonesia: telah UU n0 13 tahun 2003 tentang ketenagakerjaanatas konvensi", jurnal HAM vol 10 nomor 1 juli 2019, hal 121, dalam http://www.journalbalitbangham.go.id/index.php/au diakses pada 19 november 2019 pukul 12.40 WIB. 
bertindak agar diberlakukannya dalam menganggapi keputusan Mahkamah Agung yang merupakan untuk perlindungan yang sama dari hukum. ${ }^{11}$

Bukan hanya terhadap diskriminasi wanita hamil dan menyusui saja tetapi diskriminasi upah terdapat pada tunjangan kesejahteraan. Pada umumnya para pekerja laki-laki akan mendapatkan tunjangan kesejahteraan untuk anak dan istri, namun pada pekerja perempuan tidak mendapatkan tunjangan kesejahteraan untuk suami dan anak. Hal ini dikarenakan adanya anggapan bahwa wanita mudah diatur, bahkan anggapan ini juga berimbas pada adanya pembatasan persyaratan jabatan yang memberikan syarat pada jenis kelamin. Seperti pada persyaratan lowongan pekerjaan yang memberikan syarat pada jenis kelamin tertentu, padahal lowongan pekerjaan tersebut tidak mempunyai karakter khas yang hanya boleh dikerjakan oleh jenis kelamin tertentu. Kemudian pada jabatan strategis yang kebanyakan hanya diperuntukkan bagi pria, dimana kebanyakan pekerja wanita selalu diposisikan pada jenis-jenis jabatan yang tidak memberikan keputusan final, tentu hal ini juga merupakan salah satu merupakan diskriminasi wanita. ${ }^{12}$ Wanita yang hamil dan melahirkan atau kondisi medis harus diperlakukan sama untuk semua pekerjaan. Termasuk bukti penerimaan manfaat dibawah pinggiran mendapatkan keuntungan dari program, dan orang tersebut tidak mempengaruhi tapi mampu dalam kemampuan mereka. ${ }^{13}$

Perlindungan hak-hak perempuan pekerja dalam ketentuan perundangundangan merupakan dasar hukum bagi pekerja perempuan didalam melaksanakan hak-haknya sebagai pekerja dan perlindungan terhadap tindakan diskriminasi yang dilakukan oleh pemberi kerja serta pihak lain ditempat kerja. Hak-hak pekerja perempuan salah satunya adalah hak maternal. Hak maternal pada dasarnya sama dengan hak kesehatan reproduksi. Aspek perlindungan terhadap hak-hak maternal ini, pada dasarnya menjadi ketentuan yang wajib diharmonisasikan ke dalam peraturan perundang-undangan bidang ketenagakerjaan di Indonesia. Hak tersebut meliputi hak atas perlindungan khusus terhadap fungsi melanjutkan keturunan dalam bentuk: tidak dipecat atas dasar kehamilan atau dasar status perkawinan, pengadaan cuti hamil dengan hayaran, pengadaan pelayanan sosial dalam bentuk tempat penitipan anak, pemberian pekerjaan yang tidak berbahaya bagi kehamilan. ${ }^{14}$

Perbedaan gender prinsip dasarnya adalah sesuatu yang wajar dan merupakan sunnatullah sebagai sebuah fenomena kebudayaan. Perbedaan gender tidak menjadi

\footnotetext{
${ }^{11}$ Regina Grayer, the hidden gender of law (Australia: the federation press, 1990), 45

12 Ibid, 122

${ }^{13}$ Regina Grayer, the hidden gender of law (Australia: the federation press, 1990), 46

14 Nurjannah, "prinsip anti diskriminasi dan perlindungan hak-hak maternal pekerja perempuan dalam perspektif keadilan gender", jurnal IUS vol 1 nomor 1 april 2003, hlm 37-38, dalam http://jurnalius.ac.id/ojs/index.php/jurnalIUS/article/ diakses pada 20 november 2019 pukul 09.05
} WIB. 
masalah selama tidak menimbulkan ketidakadilan gender (gender in equalities). Namun yang menjadi persoalan adalah perbedaan gender ternyata telah melahirkan berbagai ketidakadilan baik kaum laki-laki terutama kepada kaum perempuan. ${ }^{15}$ Keadilan gender adalah proses yang adil bagi perempuan dan laki-laki. Untuk pastikan agar proses itu adil bagi yang dimainkan. Keadilan gender mengantarkan perempuan dan laki-laki menuju kesetaraan gender. Iklan gender kesetaraanalah keadaan bagi perempuan dan laki-laki menikmati status dan kondisi yang sama untuk merealisasikan hak asasinya secara penuh dan sama-sama menyelesaikan dalam menyumbangkanya dalam pembangunan, dengan demikian kesetaraan jenis kelamin adalah penilaian yang sama oleh masyarakat terhadap persamaan dan perbedaan perempuan dan laki-laki dalam berbagai peran yang mereka lakukan. ${ }^{16}$

Ketidakadilan gender merupakan sistem dan struktur dimana baik kaum lakilaki maupun perempuan menjadi korban dari sistem tersebut. Untuk memahami bagaimana perbedaan gender menyebabkan ketidakadilan gender dapat dilihat melalui berbagai manifestasi ketidakadilan yang ada. Ketidakadilan gender termanifestasikan dalam pelbagai bentuk ketidakadilan, yakni marginalisasi atau proses pemiskinan ekonomi, subordinasi atau anggapan tidak penting dalam pengambilan keputusan, pembentukan stereotype atau melalui pelabelan negatif, kekerasan (violence), beban kerja lebih panjang atau lebih banyak (burden) serta sosialisasi idiologi nilai peran gender. ${ }^{17}$

Upaya perlindungan khusus kepada pekerja perempuan diperlukan sebagai salah satu bentuk untuk mewujudkan kesetaraan gender. Upaya perlindungan ini diberikan sesuai dengan kekhususan yang dimiliki kaum perempuan. "perusahaanperusahaan harus memperhatikan berbagai keistimewaan yang khas yang menjadi hak dasar pekerja perempuan. Mereka memiliki hak khusus seperti hak cuti hamil, hak cuti melahirkan, hak cuti tertentu sebagai kodrat perempuan," dalam hubungan kerja, tidak boleh ada perlakuan diskriminasi terhadap pekerja perempuan terutama dalam pemberian upah, tunjangan keluarga dan jaminan sosial, kesempatan mengikuti pelatihan, serta promosi jabatan."Pemenuhan hak tersebut tidak boleh berlaku diskriminatif".

Kesetaraan gender dapat dilihat dari empat indikator diantaranya: (1) faktor akses, perempuan dan laki-laki akses yang sama terhadap sumber-sumber daya pembangunan (2) faktor partisipasi, perempuan dan laki-laki sama-sama berpartisipasi dalam program-program pembangunan (3) faktor manfaat, perempuan dan laki-laki harus sama-sama menikmati manfaat dari hasil

${ }^{15}$ Ridwan, kekerasan berbasis gender, 25

${ }^{16}$ Ni Made Diska Widayani dan Sri Hartati “kesetaraan dan keadilan gender dalam pandangan perempuan bali:studi fenomenologis terhadap perempuan penulis bali", jurnal psikologi Undip Vol.13 No.2 oktober 2014, hal 149-150, dalam http://ejournal.undip.ac.id/index.php/psikologi diakses pada 20 november 2019 pukul 09.00 WIB.

${ }_{17}$ Ridwan, kekerasan berbasis gender (Purwokerto: fajar pustaka, 2006), 25 
pembangunan (4) faktor kontrol, memiliki kewenangan penuh untuk mengambil keputusan atas penggunaan dan hasil sumber daya baik laki-laki dan perempuan. ${ }^{18}$

\section{KESIMPULAN}

Kesetaraan gender bukan berarti mempertimbangkan antara laki-laki dan perempuan. Akan tetapi lebih dimaknai pada upaya membangun relasi dan kesempatan yang sama antara laki-laki dan perempuan. Jadi setara disini adalah laki-laki dan perempuan menikmati status yang setara dan memiliki kondisi yang sama untuk mewujudkan secara penuh hak-hak asasi dan potensinya bagi pembangunan di segala bidang kehidupan.

18 Kaslina, "kesetaraan gender pegawai dinas pertanian" , jurnal equilibrium pendidikan sosiologi vol III no 1 mei 2005, hlm 112, dalam https://media.neliti.com/media/publications/60772ID-kesetaraan-gender-pegawai-dinas-pertania.pdf diakses pada 20 november 2019 pukul 09.15 WIB. 


\section{DAFTAR PUSTAKA}

Banjarani , Desia Rakhma. "pelaksanaan dan perlindungan akses hak pekerja wanita di Indonesia: telah UU n0 13 tahun 2003 tentang ketenagakerjaan atas konvensi", jurnal HAM vol 10 nomor 1 juli 2019, dalam http://www.journalbalitbangham.go.id/index.php/au diakses pada 19 november 2019 pukul 12.40 WIB.

Diska, Ni Made Widayani dan Sri Hartati. "kesetaraan dan keadilan gender dalam pandangan perempuan bali:studi fenomenologis terhadap perempuan penulis bali", jurnal psikologi Undip Vol.13 No.2 oktober 2014, dalam http://ejournal.undip.ac.id/index.php/psikologi diakses pada 20 november 2019 pukul 09.00 WIB.

Graycar, Regina. the hidden gender of law. Australia: the federation press, 1990.

Kaslina, "kesetaraan gender pegawai dinas pertanian", jurnal equilibrium pendidikan sosiologi vol III no 1 mei 2005, dalam https://media.neliti.com/media/publications/60772-ID-kesetaraan-genderpegawai-dinas-pertania.pdf diakses pada 20 november 2019 pukul 09.15 WIB.

Mufidah. paradigma gender. Malang: bayumedia publishing, 2003.

Muqoyyidin, Andik Wahyun. "wacana kesetaraan gender pemikiran Islam kontemporer tentang gerakan feminisme Islam", jurnal Al-Ulum, vol 13 no 2, desember2013, dalam http://www.journal.iaingorontalo.ac.id/index.php/au diakses pada 19 november 2019 pukul 12.00 WIB.

Nurjannah. "prinsip anti diskriminasi dan perlindungan hak-hak maternal pekerja perempuan dalam perspektif keadilan gender", jurnal IUS vol 1 nomor 1 april 2003. Dalam http://jurnalius.ac.id/ojs/index.php/jurnalIUS/article/ diakses pada 20 november 2019 pukul 09.05 WIB.

Ridwan, kekerasan berbasis gender. Purwokerto: fajar pustaka, 2006.

Rahmawaty, Anita. "harmoni dalam keluarga perempuan karir: upaya mewujudkan kesetaraan dan keadilan gender dalam keluarga", jurnal palastren, vol 8 no 01 juni 2015,

dalam https://www.ingentaconnect.com/content/doaj/19796056/2016/00000008/00 000001/art00001/supp-data;jsessionid=2wppn6nk82jsk.x-ic-live-01 diakses pada 20 november 2019 pukul 09.20 WIB.

Suhra, Sarifa. "kesetaraan gender dalam perspektif AL-Qur'an dan implikasinya terhadap hukum Islam", jurnal Al-Ulum, vol 13 no 2, desember 2013, dalam http://www.journal.iaingorontalo.ac.id/index.php/au diakses pada 19 november 2019 pukul 12.00 WIB. 